\title{
Activation of PAC1 receptors in rat cerebellar granule cells stimulates both calcium mobilization from intracellular stores and calcium influx through $\mathrm{N}$-type calcium channels
}

\author{
Magali Basille-Dugay ${ }^{1,2,3,4}$, Hubert Vaudry ${ }^{1,2,3,4}$, Alain Fournier ${ }^{4,5}$, Bruno Gonzalez ${ }^{2,6}$ and David Vaudry ${ }^{1,2,3,4}$ * \\ 1 INSERM U982, Laboratory of Neuronal and Neuroendocrine Differentiation and Communication, University of Rouen, Mont-Saint-Aignan, France \\ 2 Institute for Research and Innovation in Biomedicine, University of Rouen, Mont-Saint-Aignan, France \\ ${ }^{3}$ PRIMACEN, University of Rouen, Mont-Saint-Aignan, France \\ ${ }^{4}$ International Associated Laboratory Samuel de Champlain, University of Rouen, Mont-Saint-Aignan, France \\ ${ }^{5}$ Institut National de la Recherche Scientifique-Institut Armand Frappier, University of Québec, Laval, QC, Canada \\ ${ }^{6}$ Région INSERM ERI28, Laboratory of Microvascular Endothelium and Neonate Lesions, University of Rouen, Rouen, France
}

\section{Edited by:}

Jae Young Seong, Korea University,

South Korea

Reviewed by:

Hitoshi Hashimoto, Osaka University, Japan

Dora Reglodi, University of Pecs, Hungary

*Correspondence:

David Vaudry, INSERM U982,

Laboratory of Neuronal and

Neuroendocrine Differentiation and Communication, International

Associated Laboratory Samuel de Champlain, University of Rouen, 76821 Mont-Saint-Aignan, Rouen, France.

e-mail:david.vaudry@univ-rouen.fr
High concentrations of pituitary adenylate cyclase-activating polypeptide (PACAP) and a high density of PACAP binding sites have been detected in the developing rat cerebellum. In particular, PACAP receptors are actively expressed in immature granule cells, where they activate both adenylyl cyclase and phospholipase $\mathrm{C}$. The aim of the present study was to investigate the ability of PACAP to induce calcium mobilization in cerebellar granule neurons. Administration of PACAP-induced a transient, rapid, and monophasic rise of the cytosolic calcium concentration $\left(\left[\mathrm{Ca}^{2+}\right]_{\mathrm{i}}\right)$, while vasoactive intestinal peptide was devoid of effect, indicating the involvement of the $\mathrm{PAC} 1$ receptor in the $\mathrm{Ca}^{2+}$ response. Preincubation of granule cells with the $\mathrm{Ca}^{2+}$ ATPase inhibitor, thapsigargin, or the D-myo-inositol 1,4,5trisphosphate $\left(\mathrm{IP}_{3}\right)$ receptor antagonist, 2-aminoethoxydiphenyl borate, markedly reduced the stimulatory effect of PACAP on $\left[\mathrm{Ca}^{2+}\right]_{i}$. Furthermore, addition of the calcium chelator, EGTA, or exposure of cells to the non-selective $\mathrm{Ca}^{2+}$ channel blocker, $\mathrm{NiCl}_{2}$, significantly attenuated the PACAP-evoked $\left[\mathrm{Ca}^{2+}\right]_{i}$ increase. Preincubation of granule neurons with the $\mathrm{N}$-type $\mathrm{Ca}^{2+}$ channel blocker, $\omega$-conotoxin GVIA, decreased the PACAP-induced $\left[\mathrm{Ca}^{2+}\right]_{i}$ response, whereas the L-type $\mathrm{Ca}^{2+}$ channel blocker, nifedipine, and the $\mathrm{P}$ - and Q-type $\mathrm{Ca}^{2+}$ channel blocker, $\omega$-conotoxin MVIIC, had no effect. Altogether, these findings indicate that PACAP, acting through PAC1 receptors, provokes an increase in $\left[\mathrm{Ca}^{2+}\right]_{i}$ in granule neurons, which is mediated by both mobilization of calcium from $I \mathrm{P}_{3}$-sensitive intracellular stores and activation of $\mathrm{N}$-type $\mathrm{Ca}^{2+}$ channel. Some of the activities of PACAP on proliferation, survival, migration, and differentiation of cerebellar granule cells could thus be mediated, at least in part, through these intracellular and/or extracellular calcium fluxes.

Keywords: pituitary adenylate cyclase-activating polypeptide, cerebellum, granule cells, calcium, cytoplasmic calcium stores, calcium channels, autoradiography

\section{INTRODUCTION}

Pituitary adenylate cyclase-activating polypeptide (PACAP) is a 38- or 27-amino acid peptide that was isolated from hypothalamic extracts for its ability to stimulate cAMP formation in anterior pituitary cells (Miyata et al., 1989). PACAP belongs to a superfamily of peptides that originate from a common ancestral sequence and have evolved through exon and gene duplications. In particular, PACAP27 exhibits $68 \%$ identity with vasoactive intestinal peptide (VIP). The sequence of PACAP has been very well conserved during evolution, suggesting that it may exert vital physiological activities (Vaudry et al., 2009). Indeed, numerous studies

Abbreviations: 2APB, 2-aminoethoxydiphenyl borate; $\mathrm{Ca}^{2+}$, calcium; $\left[\mathrm{Ca}^{2+}\right]_{\mathrm{i}}$, intracellular calcium concentration; EGTA, ethylene glycol-bis ( $\beta$-aminoethylether)$\mathrm{N}, \mathrm{N}, \mathrm{N}^{\prime}, \mathrm{N}^{\prime}$-tetraacetic acid; P, postnatal day; PACAP, pituitary adenylate cyclaseactivating polypeptide; PACAP27, 27-amino acid form of PACAP; PACAP38, 38-amino acid form of PACAP; VIP, vasoactive intestinal peptide. have shown that PACAP is widely expressed throughout the body and regulates a large array of biological functions, both in the central nervous system and in peripheral organs (Reglodi et al., 2012).

Three PACAP/VIP receptors, which belong to the class B family of seven-transmembrane $G$ protein-coupled receptors, have been cloned and termed respectively PAC1, VPAC1, and VPAC2, according to their relative affinity for PACAP and VIP (Harmar et al., 2012). PAC1 recognizes PACAP27 and PACAP38 with 1000-fold higher affinity than VIP while, VPAC1 and VPAC2 exhibit similar affinity for both PACAP and VIP (Cauvin et al., 1990). All three receptors can activate a variety of second messengers including cAMP, cGMP, $\mathrm{IP}_{3}$, or calcium, depending on the receptor types, splice variants, $G$ proteins, and other intracellular components expressed by each cell type (Vaudry et al., 2009). This cellular context plays a crucial role in determining the effects of PACAP, as differential expression of PACl splice variants is sufficient to 
trigger opposite activities on neuronal precursor proliferation (Nicot and DiCicco-Bloom, 2001).

It was initially shown that PACAP can increase calcium ion concentration in pituitary gonadotrope, somatotrope, and somatolactotrope cells (Canny et al., 1992; Gracia-Navarro et al., 1992; Matsuda et al., 2008). PACAP also induces calcium mobilization in chromaffin cells (Watanabe et al., 1992), hippocampal neurons (Tatsuno et al., 1992), folliculo-stellate cells (Yada et al., 1993), and type-2 astrocytes (Tatsuno and Arimura, 1994). Several transduction pathways are clearly involved in the effect of PACAP on calcium fluxes. For instance, in somatotrope cells, PACAP activates calcium mobilization in a cAMP- and protein kinase-A-dependent manner (Rawlings et al., 1993) while in gonadotrope cells, PACAP increases calcium through an inositol trisphosphate-dependent mechanism (Rawlings et al., 1994). Calcium mobilization induced by PACAP is essential for stimulation of acetylcholine (Masuo et al., 1993), catecholamine (Isobe et al., 1993), and insulin (Yada et al., 1994) release. Besides triggering neurosecretion, calcium influx also activates a variety of transcription factors that control gene expression involved in long-lasting changes of neuronal function. For instance, cAMP-dependent calcium mobilization is required for the ability of PACAP to regulate astrocyte differentiation (Cebolla et al., 2008).

In suprachiasmatic neurons, PACAP activates L-type calcium channel conductance by activating the MAPK pathway (Dziema and Obrietan, 2002). In this model, PACAP can either induce transient calcium mobilization (Dziema and Obrietan, 2002) or increase the amplitude and/or frequency of spontaneous calcium spikes (Michel et al., 2006). In cultured granule cells, some studies report that PACAP fails to increase calcium levels (Aoyagi and Takahashi, 2001) while others indicate that PACAP induces calcium mobilization (Mei, 1999). In cerebellar tissue slices, PACAP has no effect on the frequency of calcium transients but decreases the amplitude of calcium oscillations in granule cells (Cameron et al., 2007). Since PACAP exerts important neurodevelopmental and neuroprotective activities in the cerebellum (Botia et al., 2007), and since calcium plays a pivotal role in the control of cell proliferation, migration, and differentiation of granule cells (Sato et al., 2005), the aim of the present study was to investigate the ability of PACAP to induce calcium mobilization in cerebellar granule neurons and to characterize the channels involved.

\section{MATERIALS AND METHODS \\ ANIMALS}

Wistar rats were obtained from a colony raised at the University of Rouen in an accredited animal facility (approval B.76-451-04), according to the French recommendations for the care and use of laboratory animals. All experiments were performed in accordance with the French Ministry of Agriculture and the European Communities Council Directive 2010/63/UE of September 22, 2010 (approval number N/01-12-11/24/12-14) under the supervision of authorized investigators (David Vaudry, Magali BasilleDugay). Animals were housed in a temperature-controlled room $\left(22 \pm 1^{\circ} \mathrm{C}\right)$ under a 12-h light/dark cycle and with ad libitum access to food and water. Pups, of both sexes, were killed by decapitation at postnatal day 8 (P8) and the cerebella were quickly dissected out.

\section{REAGENTS}

The 38-amino acid form of PACAP (PACAP38) was synthesized by solid phase methodology as previously described (Jolivel et al., 2009). PACAP27 and VIP were obtained from PolyPeptide Laboratories (Strasbourg, France). Fluo-3 acetoxymethylester (Fluo-3/AM) was from Molecular Probes (Invitrogen, Cergy Pontoise, France). Thapsigargin, ethylene glycol-bis $(\beta$-aminoethylether $)-\mathrm{N}, \mathrm{N}, \mathrm{N}^{\prime}, \mathrm{N}^{\prime}$-tetraacetic acid (EGTA), nifedipine, $\omega$-conotoxin GVIA, and $\omega$-conotoxin MVIIC were purchased from Sigma-Aldrich (Saint-Quentin Fallavier, France). 2-aminoethoxydiphenyl borate (2APB) was from Fisher Scientific (Illkirch, France).

\section{CELL CULTURE}

Granule cell suspensions were prepared from cerebella of P8 rats, as previously described (Kaddour et al., 2013). For calcium experiments, dispersed cells were seeded on poly-L-lysine-coated glass coverslips in Falcon 3001 dishes at a density of $1 \times 10^{6}$ cells $/ \mathrm{mL}$ in a cultured medium consisting of 75\% DMEM and 25\% Ham's F12 supplemented with $10 \%$ fetal bovine serum, $25 \mathrm{mM} \mathrm{KCl}$, and $1 \%$ antibiotic antimycotic solution. Cells were grown at $37^{\circ} \mathrm{C}$ in a humidified incubator with an atmosphere of 5\% $\mathrm{CO}_{2} / 95 \%$ air. After $20 \mathrm{~h}$, cytosine arabinoside, a mitotic inhibitor, was added at a final concentration of $5 \mu \mathrm{M}$ to avoid replication of non-neuronal cells. In these conditions, the culture mainly contains cerebellar granule cells and contaminant cells are mostly astrocytes, which can be recognized based on their morphology (Levi et al., 1989).

\section{CALCIUM MEASUREMENT}

Forty-eight hours after plating, granule cells were loaded at $37^{\circ} \mathrm{C}$ for $45 \mathrm{~min}$ with $5 \mu \mathrm{M}$ fluo-3/AM diluted in culture medium. Then, the calcium-dye-probe was washed off and replaced with a Ringer's solution containing $10 \mathrm{mM}$ Hepes, $120 \mathrm{mM} \mathrm{NaCl}, 2 \mathrm{mM}$ $\mathrm{KCl}, 1.8 \mathrm{mM} \mathrm{CaCl}_{2}, 1 \mathrm{mM} \mathrm{MgCl}$, and $6 \mathrm{mM}$ glucose (pH 7.4). Under certain conditions, pharmacological agents were added in the Ringer's solution 30 min before mounting the glass coverslip on the stage of a Nikon inverted microscope (Eclipse TE200) equipped with a Nikon $60 x, 1.4$ NA, oil-immersion objective. Fluo-3/AM was excited with the 488-nm laser line, and the emitted fluorescence was recorded with a 500-nm long-pass filter on a Noran OZ confocal laser-scanning microscope (Noran Instruments, Middleton, WI, USA), equipped with a standard argon/kripton laser for illumination. Images were acquired as a time series of scan of the same focal plane $(512 \times 480$ pixels at 7.5 images/s $)$ and data processing was carried out using the Intervision software (Noran Instruments). The cells were continuously perifused with Ringer's solution at constant flow rate $(2 \mathrm{~mL} / \mathrm{min})$ and temperature $\left(37^{\circ} \mathrm{C}\right)$. The perifusion system was also used to deliver test substances at the vicinity of the cultured neuroblasts. Any modification of fluorescence directly reflects a change of intracellular calcium concentration $\left(\left[\mathrm{Ca}^{2+}\right]_{\mathrm{i}}\right)$. To determine the increase of $\left[\mathrm{Ca}^{2+}\right]_{\mathrm{i}}$, the value of the peak amplitude as well as the area under the curve (AUC) of each response profile were calculated by using the PRISM Software (GraphPad Software, San Diego, CA, USA). Results are expressed as histograms showing (i) the distribution of cells according to the amplitude of their response to PACAP and (ii) the mean AUCs of their $\left[\mathrm{Ca}^{2+}\right]_{i}$ increase. 


\section{BINDING STUDIES}

PACAP27 was radioiodinated by means of the lactoperoxidase technique as previously described (Basille et al., 1994). The radioligand was purified by reverse-phase HPLC on a Vydac $\mathrm{C}_{18}$ column $(25 \times 0.46 \mathrm{~cm}$; Sigma-Aldrich $)$, using a gradient of acetonitrile/water containing $0.1 \%$ TFA. The specific radioactivity of the tracer was approximately $800 \mathrm{Ci} / \mathrm{mmol}$.
Twenty- $\mu \mathrm{m}$-thick sections or granule cells from $\mathrm{P} 8$ rat cerebella cultured for 1 day were preincubated at $20^{\circ} \mathrm{C}$ in $50 \mathrm{mM}$ Tris buffer ( $\mathrm{pH}$ 7.4) supplemented with $1 \%$ bovine serum albumin (BSA), $32 \mathrm{mM}$ saccharose, $5 \mathrm{mM} \mathrm{MgCl}_{2}$, and $0.5 \mu \mathrm{g} / \mathrm{mL}$ bacitracin, for 30 or $10 \mathrm{~min}$, respectively. Sections or cells were incubated with $\left[{ }^{125} \mathrm{I}\right] \mathrm{PACAP} 27$ (40 or $400 \mathrm{pM}$, respectively) at $20^{\circ} \mathrm{C}$ for $1 \mathrm{~h}$ in the same buffer, supplemented with $2 \%$ BSA. To visualize non-specific
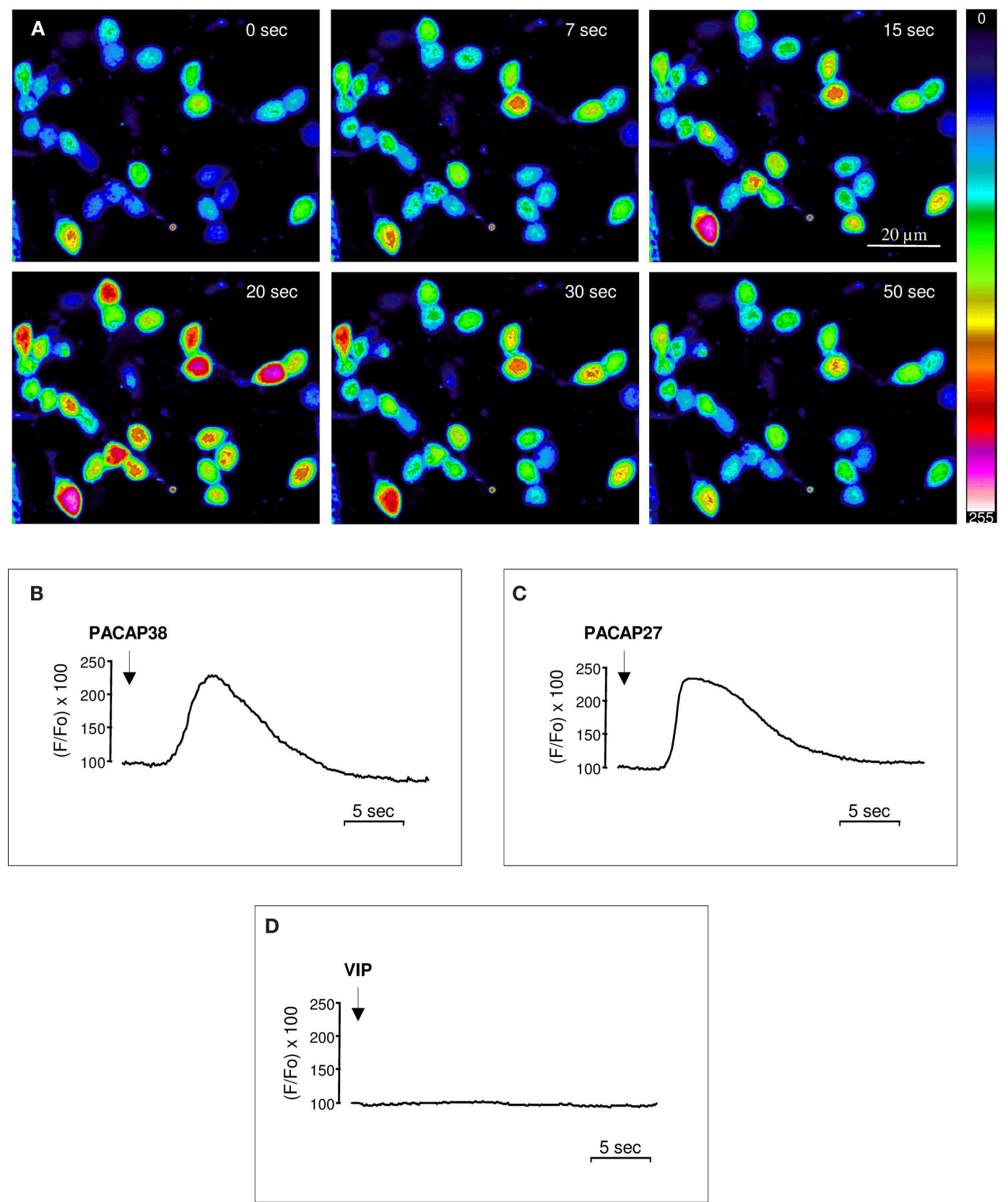

FIGURE 1 | Effect of PACAP38, PACAP27, or VIP on $\left[\mathrm{Ca}^{2+}\right]_{i}$ in cultured cerebellar granule cells. (A) Time series of pseudocolor images illustrating the $\left[\mathrm{Ca}^{2+}\right]_{i}$ changes in cultured granule cells loaded with the $\mathrm{Ca}^{2+}$-sensitive dye fluo-3/AM after infusion of $10^{-6} \mathrm{M}$ PACAP38 at the vicinity of the cells. The pseudocolor scale indicates the corresponding
$\left[\mathrm{Ca}^{2+}\right]_{\mathrm{i}}$ changes expressed in arbitrary units. (B-D) Typical profiles illustrating the time-course of the variation of the fluorescence ratio evoked by a single application of $10^{-6} \mathrm{M}$ PACAP38 (B), PACAP27 (C), or VIP (D) on $\left[\mathrm{Ca}^{2+}\right]_{\mathrm{i}}$ in cultured granule cells. The arrows indicate the onset of peptide application. 


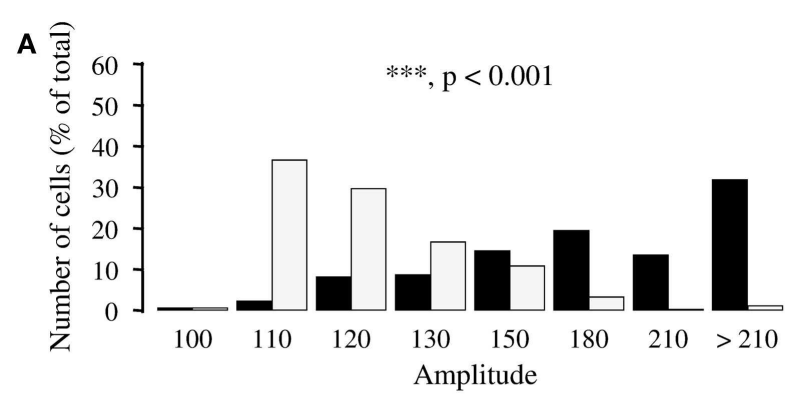

PACAP38 $\square$ thapsigargin + PACAP38

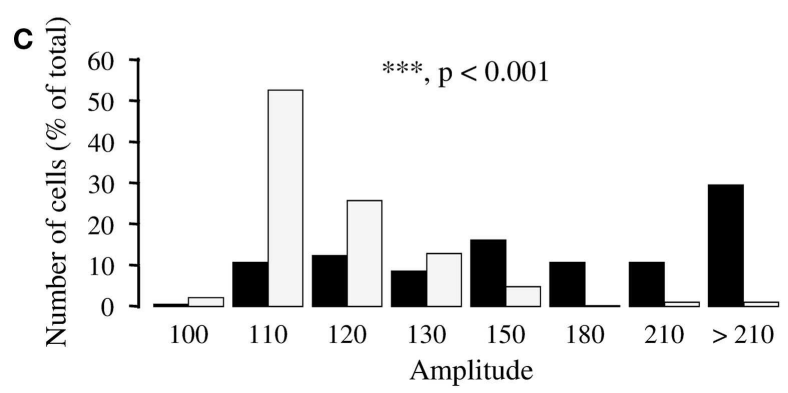

PACAP38 $\square$ 2APB + PACAP38
B

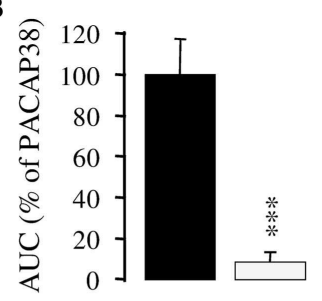

PACAP38 $\square$ thapsigargin + PACAP38

D

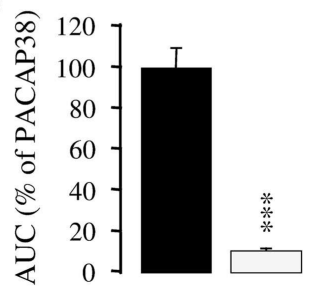

PACAP38 $\square$ 2APB + PACAP38
FIGURE 2 | Involvement of intracellular calcium stores in the mechanism of action of PACAP38 in cerebellar granule cells. (A-D)

Effect of a single application of $10^{-6} \mathrm{M}$ PACAP38 on the amplitude $(\mathbf{A}, \mathbf{C})$ and the area under the curve (B,D) of the $\left[\mathrm{Ca}^{2+}\right]_{i}$ response in the absence (black bars) or presence (white bars) of $10^{-6} \mathrm{M}$ thapsigargin, a $\mathrm{Ca}^{2+}$ ATPase inhibitor, or $10^{-5} \mathrm{M} 2 \mathrm{APB}$, a membrane permeable D-myo-inositol 1,4,5-trisphosphate receptor antagonist. Thapsigargin and 2APB were added 15 and 30 min before application of the pulse of PACAP, respectively. $(\mathbf{A}, \mathbf{C})$ Histograms showing the distribution of granule cells according to the amplitude of their response to PACAP. Each graph represents the analysis of a least 50 cells from 3 different cultures. 2APB, 2-aminoethoxydiphenyl borate; AUC, area under the curve. ${ }^{* *} p<0.001$. binding, slices, or cells were incubated with the radioligand in the presence of $10^{-6} \mathrm{M}$ PACAP38. At the end of the incubation, sections, or cells were washed with cold Tris buffer and dried under an air stream. Finally, slices were apposed onto Hyperfilm-3H (GE Healthcare, Les Ulis, France) for 6 days and the radioactivity associated with the cells was counted in a gamma-counter (LKB, Wallac, Rockville, MI, USA). Tissue slices were photographed by means of a computer-assisted image-analysis station (Samba, Grenoble, Lyon).

\section{STATISTICAL ANALYSIS}

Data are expressed as mean \pm SEM values from at least three independent experiments. Statistical analyses were conducted with the PRISM software.

\section{RESULTS}

\section{EFFECT OF PACAP38, PACAP27, AND VIP ON $\left[\mathrm{Ca}^{2+}\right] \mathrm{i}$}

Perifusion of cultured cerebellar granule cells with $10^{-6} \mathrm{M}$ PACAP38 provoked a marked increase of $\left[\mathrm{Ca}^{2+}\right]_{i}$ in more than $90 \%$ of the cells (Figure 1A). In all responding cells $\left[\mathrm{Ca}^{2+}\right]_{\mathrm{i}}$ increased rapidly, i.e., within less than $5 \mathrm{~s}$ following PACAP infusion, and reached a maximum after 15-20 s, but the amplitude of the response was variable depending on the cell (Figure 1A). The response profile determined as the ratio between the fluo-3 fluorescence intensity under resting conditions and after exposure to test substances, revealed that both PACAP38 and PACAP27 $\left(10^{-6} \mathrm{M}\right)$ induced a transient, rapid, and monophasic increase in $\left[\mathrm{Ca}^{2+}\right]_{\mathrm{i}}$ followed by gradual return to baseline (Figures 1B,C) while application of vehicle had no effect. Conversely, administration of $10^{-6} \mathrm{M}$ VIP did not induce any modification of the $\left[\mathrm{Ca}^{2+}\right]_{\mathrm{i}}$ level (Figure 1D). When the same cells were exposed to a second pulse of PACAP, the stimulatory effect of the peptide on $\left[\mathrm{Ca}^{2+}\right]_{\mathrm{i}}$ was totally abolished (data not shown).

\section{CONTRIBUTION OF INTRACELLULAR $\mathrm{Ca}^{2+}$ POOLS IN THE PACAP38-EVOKED INCREASE OF $\left[\mathrm{Ca}^{2+}\right] \mathrm{i}$}

Preincubation of granule cells with the $\mathrm{Ca}^{2+}$ ATPase inhibitor thapsigargin $\left(10^{-6} \mathrm{M} ; 15 \mathrm{~min}\right)$ induced a substantial reduction of the amplitude of the $\left[\mathrm{Ca}^{2+}\right]_{\mathrm{i}}$ response to $10^{-6} \mathrm{M}$ PACAP38 in most cells ( $p<0.001$; Figure $2 \mathrm{~A})$. Indeed, in the absence of thapsigargin, more than $80 \%$ of the responding cells exhibited at least a $50 \%$ increase of their fluorescence intensity whereas in the presence of the inhibitor, $80 \%$ of the cells exhibited an increase of their fluorescence intensity that was lower than 30\% (Figure 2A). As shown in Figure 2B, 


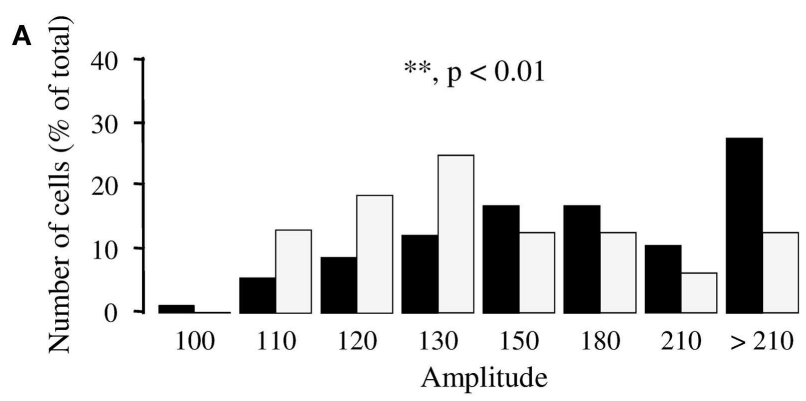

PACAP38 $\square$ EGTA+ PACAP38
B

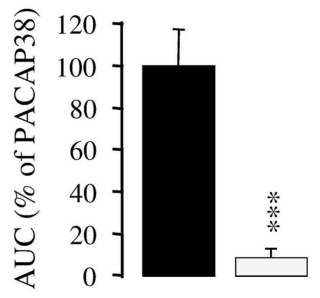

PACAP38 $\square$ EGTA + PACAP38

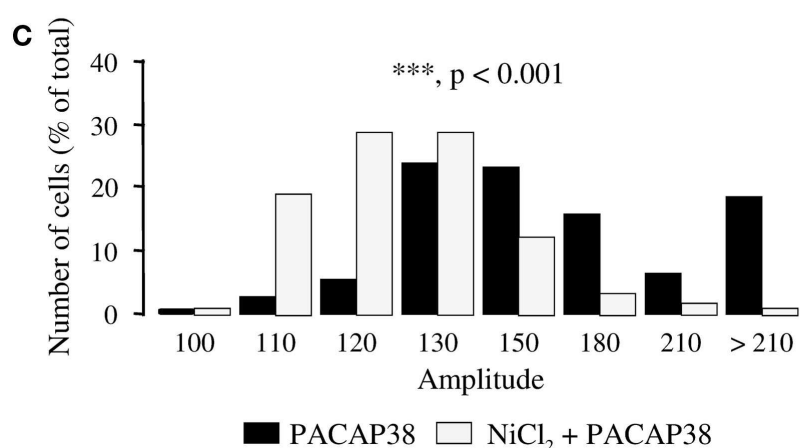

D

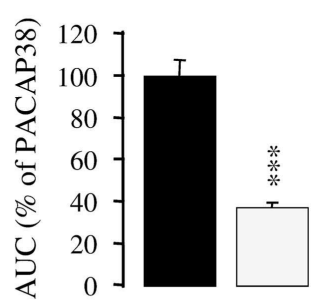

PACAP38 $\square \mathrm{NiCl}_{2}+$ PACAP38
FIGURE 3 | Involvement of calcium influx in the mechanism of action of PACAP38 in cerebellar granule cells. (A-D) Effect of a single application of $10^{-6} \mathrm{M}$ PACAP38 on the amplitude $(\mathbf{A}, \mathbf{C})$ and the area under the curve $(\mathbf{B}, \mathbf{D})$ of the $\left[\mathrm{Ca}^{2+}\right]_{\mathrm{i}}$ response in the absence (black bars) or presence (white bars) of $6 \mathrm{mM}$ EGTA, a $\mathrm{Ca}^{2+}$ chelator, or $3 \mathrm{mM} \mathrm{NiCl}_{2}$, a blocker of voltage-operated calcium channels. EGTA and $\mathrm{NiCl}_{2}$ were added to the incubation medium
10 min before application of the pulse of PACAP. (A,C) Histograms showing the distribution of granule cells according to the amplitude of their response to PACAP. Each graph represents the analysis of a least 50 cells from 3 different cultures. AUC, area under the curve; EGTA, ethylene glycol-bis( $\beta$-aminoethylether)-N, $\mathrm{N}, \mathrm{N}^{\prime}, \mathrm{N}^{\prime}$-tetraacetic acid; $\mathrm{NiCl}_{2}$, nickel chloride. ${ }^{* *} p<0.01,{ }^{* * *} p<0.001$. thapsigargin reduced by $86 \%$ the mean AUC of the PACAP38evoked $\left[\mathrm{Ca}^{2+}\right]_{i}$ response $(p<0.001)$. Preincubation of granule cells with the permeable D-myo-inositol 1,4,5-trisphosphate receptor antagonist $2 \mathrm{APB}\left(10^{-5} \mathrm{M}\right)$ markedly reduced the $\left[\mathrm{Ca}^{2+}\right]_{\mathrm{i}}$ response to $10^{-6} \mathrm{M}$ PACAP38. In the presence of $2 \mathrm{APB}$, more than $90 \%$ of responding cells exhibited an increase of their fluorescence intensity that was lower than $30 \% \quad(p<0.001$; Figure 2C). As shown in Figure 2D, 2APB reduced by $89 \%$ the mean AUC of the PACAP38-evoked $\left[\mathrm{Ca}^{2+}\right]_{i}$ response $(p<0.001)$.

\section{CONTRIBUTION OF EXTRACELLULAR $\mathrm{Ca}^{2+}$ IN THE PACAP38-EVOKED STIMULATION OF $\left[\mathrm{Ca}^{2+}\right] \mathrm{i}$}

Preincubation of granule cells with the calcium chelator EGTA $(6 \mathrm{mM} ; 10 \mathrm{~min})$, significantly attenuated the amplitude of the $\left[\mathrm{Ca}^{2+}\right]_{\mathrm{i}}$ response to $10^{-6} \mathrm{M}$ PACAP38 $(p<0.01$; Figure $3 \mathrm{~A})$ and diminished by $91 \%$ the AUC of the PACAP38-evoked $\left[\mathrm{Ca}^{2+}\right]_{\mathrm{i}}$ increase $(p<0.001$; Figure 3B). Similarly, a 10-min preincubation with $3 \mathrm{mM} \mathrm{NiCl}$, a blocker of voltage-operated calcium channels (VOCCs), significantly reduced the amplitude of the $\left[\mathrm{Ca}^{2+}\right]_{\mathrm{i}}$ peak in response to $10^{-6} \mathrm{M}$ PACAP38 $(p<0.001$; Figure $3 \mathrm{C})$. Indeed, while $90 \%$ of the responding cells had a ratio of fluorescence intensity greater than 130 in the absence of $\mathrm{NiCl}_{2}, 79 \%$ of them had an amplitude lower than 130 in the presence of the VOCC blocker (Figure 3C). Furthermore, addition of $\mathrm{NiCl}_{2}$ to the Ringer's solution reduced by $62 \%$ the AUC of the PACAP38-evoked $\left[\mathrm{Ca}^{2+}\right]_{\mathrm{i}}$ response $(p<0.001$; Figure 3D).

\section{ABSENCE OF EFFECT OF EGTA ON [125I]PACAP27 BINDING}

To verify that EGTA did not influence PACAP binding on its recognition sites, autoradiography experiments were carried out using $\left[{ }^{125} \mathrm{I}\right] \mathrm{PACAP} 27$ as a radioligand. As previously reported $\left[{ }^{125} \mathrm{I}\right] \mathrm{PACAP} 27$ binding was observed in the external granule cell layer of P8 rat cerebella (Figure 4A). Addition of $10^{-6}$ M PACAP38 to the incubation medium completely displaced $\left[{ }^{125} \mathrm{I}\right] \mathrm{PACAP} 27$ binding (Figure 4B). In the presence of $6 \mathrm{mM}$ EGTA, specific binding of $\left[{ }^{125} \mathrm{I}\right] \mathrm{PACAP} 27$ on cerebellar tissue slices was not impaired (Figure 4C) and displacement of $\left[{ }^{125} \mathrm{I}\right]$ PACAP27 binding by PACAP38 was not affected (Figure 4D). Binding experiments were also performed on 1-day-old cultured granule cells with $\left[{ }^{125} \mathrm{I}\right] \mathrm{PACAP} 27$ as a radioligand and it appeared that $6 \mathrm{mM}$ EGTA did not modify the specific binding of $\left[{ }^{125} \mathrm{I}\right] \mathrm{PACAP} 27$ on cultured cells (Figure 4E). 

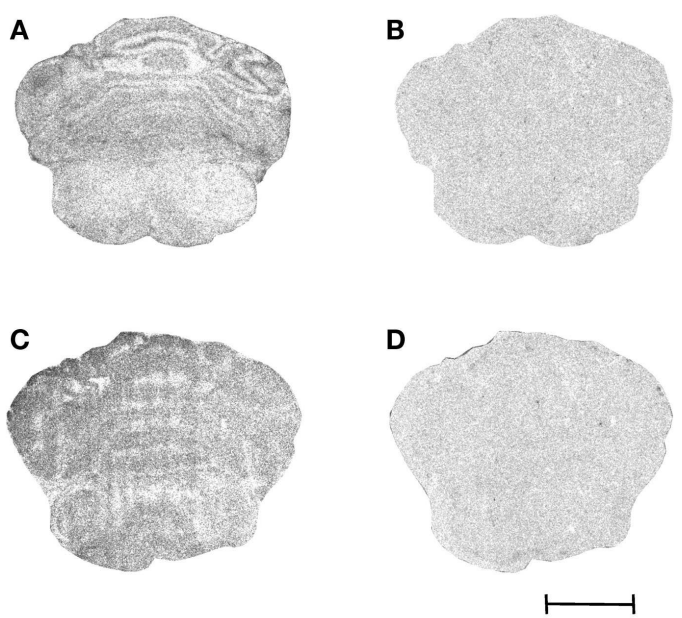

$$
\text { E }
$$

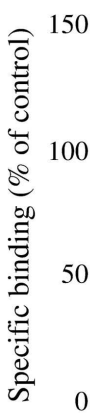

$$
\begin{array}{lll}
\text { Hepes } & + & + \\
\text { Hepes + EGTA } & - & +
\end{array}
$$

FIGURE 4 | Effect of the $\mathrm{Ca}^{2+}$ chelator EGTA (6 mM) on [25]]PACAP27 binding to cerebellar tissue slices or cerebellar granule cells. (A-D) Autoradiographic visualization of [ ${ }^{125}$ ] $]$ PACAP27 binding sites in the absence $(\mathbf{A}, \mathbf{C})$ or presence of $10^{-6} \mathrm{M}$ PACAP38 (B,D) in consecutive sections of P8 rat cerebellum. Scale bar $=1.7 \mathrm{~mm}$. (E) Histograms showing specific binding of [ ${ }^{125}$ I]PACAP27 in the absence (black bars) or presence (white bars) of 6 mM EGTA on cultured cerebellar granule cells. EGTA, ethylene glycol-bis( $\beta$-aminoethylether)-N, N, $N^{\prime}, N^{\prime}$-tetraacetic acid. NS, not significantly different from Hepes buffer.

\section{INVOLVEMENT OF N-TYPE CALCIUM CHANNELS IN THE PACAP38-EVOKED STIMULATION OF $\left[\mathrm{Ca}^{2+}\right] \mathrm{i}$}

To determine which type of $\mathrm{Ca}^{2+}$ channel is responsible for the stimulatory effect of PACAP38 on calcium influx, selective blockers of VOCCs were used. A 30-min incubation of cultured granule cells with the L-type $\mathrm{Ca}^{2+}$ channel blocker nifedipine $\left(10^{-5} \mathrm{M}\right.$; Figures 5A,B) or the $\mathrm{P}$ - and Q-type $\mathrm{Ca}^{2+}$ channel blocker $\omega$ conotoxin MVIIC $\left(10^{-6} \mathrm{M}\right.$; Figures 5C,D) did not significantly modify the amplitude of the $\left[\mathrm{Ca}^{2+}\right]_{\mathrm{i}}$ response to $10^{-6} \mathrm{M}$ PACAP38 $(p>0.05$; Figures 5A,C). Consistent with these observations, nifedipine, and $\omega$-conotoxin MVIIC did not impair the AUCs of the PACAP38-induced $\left[\mathrm{Ca}^{2+}\right]_{\mathrm{i}}$ rise $(p>0.05$; Figures $5 \mathrm{~B}, \mathrm{D})$. In contrast, preincubation of cells with the N-type $\mathrm{Ca}^{2+}$ channel blocker $\omega$-conotoxin GVIA $\left(10^{-6} \mathrm{M}\right.$; $30 \mathrm{~min}$; Figures 5E,F) provoked a significant decrease of the amplitude of the $\left[\mathrm{Ca}^{2+}\right]_{\mathrm{i}}$ increase induced by $10^{-6} \mathrm{M}$ PACAP38, with 76 and $52 \%$ of responding cells exhibiting a ratio of fluorescence intensity greater than 130 in the absence or presence of $\omega$-conotoxin GVIA, respectively $(p<0.001$; Figure $5 \mathrm{E})$. Furthermore, $\omega$-conotoxin GVIA reduced by $46 \%$ the AUC of the PACAP38-evoked $\left[\mathrm{Ca}^{2+}\right]_{\mathrm{i}}$ response $(p<0.001$; Figure 5F).

\section{DISCUSSION}

The respective contribution of extracellular and intracellular $\mathrm{Ca}^{2+}$ pools in PACAP-induced $\left[\mathrm{Ca}^{2+}\right]_{\mathrm{i}}$ increase in cerebellar neuroblasts has not been previously investigated. Because primary cultures of rat cerebellar granule cells are mainly composed of a single population of cells, the effect of PACAP on the $\left[\mathrm{Ca}^{2+}\right]_{\mathrm{i}}$ response could be monitored on a large number of neurons. Thus, we found that, in $90 \%$ of granule cells, infusion of $10^{-6} \mathrm{M}$ PACAP38 or PACAP27 induced a transient, rapid, and monophasic $\left[\mathrm{Ca}^{2+}\right]_{\mathrm{i}}$ rise, similar to the PACAP-induced $\mathrm{Ca}^{2+}$ response observed in neural NG108-15 cells (Holighaus et al., 2011) but different from that observed in rat pancreatic acinar AR42J cells (Barnhart et al., 1997) or human neuroblastoma NB-OK-1 cells (Delporte et al., 1993) in which the initial peak is followed by a plateau phase that lasts for approximately 2-3 min before the return of $\left[\mathrm{Ca}^{2+}\right]_{\mathrm{i}}$ to baseline level. These differences could be explained by the diversity of the PACAP receptor subtype repertoire expressed in each cell type and by the different intracellular signaling systems involved. For instance, in rat gonadotrophs, PACAP stimulates $\mathrm{Ca}^{2+}$ oscillations through activation of VPAC1 coupled to a PTX-insensitive G protein and phospholipase C- $\beta$ (Hezareh et al., 1996) whereas, in cerebellar neurons, in which VIP failed to affect $\left[\mathrm{Ca}^{2+}\right]_{i}$, the ability of PACAP to induce $\left[\mathrm{Ca}^{2+}\right]_{\mathrm{i}}$ rise can be ascribed to activation of the PAC1 receptor, as previously reported in primary cultures of rat cortical neurons and astrocytes (Grimaldi and Cavallaro, 1999). In neural NG108-15 cells, the PACAP38-evoked $\left[\mathrm{Ca}^{2+}\right]_{\mathrm{i}}$ response is mainly mediated by the PAC1 hop1 splice variant (Mustafa et al., 2007; Holighaus et al., 2011), an isoform also expressed in granule neurons (Kienlen-Campard et al., 1997). Interestingly, this hop isoform has been reported to be mandatory for calcium influx in cortical precursors (Yan et al., 2013). In $\beta$-islet cells, the PAC1 TM4 splice variant increases $\left[\mathrm{Ca}^{2+}\right]_{\mathrm{i}}$ by stimulating $\mathrm{Ca}^{2+}$ influx via a L-type $\mathrm{Ca}^{2+}$ channel without activating adenylyl cyclase or phospholipase C in response to PACAP (Chatterjee et al., 1996). In cerebellar granule cells, the TM4 splice variant is expressed at a very low level (Chatterjee et al., 1996) and is thus probably not functionally relevant considering the strong activation of the cAMP pathway evoked by PACAP (Basille et al., 1993, 1995).

It has previously been demonstrated that, in cerebellar granule neurons, PACAP activates the phospholipase C pathway (Basille et al., 1995). We have thus explored the possible contribution of intracellular $\mathrm{Ca}^{2+}$ stores in the stimulatory effect of PACAP on $\left[\mathrm{Ca}^{2+}\right]_{\mathrm{i}}$. The results showed that depletion of the endoplasmic reticulum $\mathrm{Ca}^{2+}$ store with the $\mathrm{Ca}^{2+}$ ATPase inhibitor thapsigargin reduced the amplitude and the AUC of the PACAP-evoked $\left[\mathrm{Ca}^{2+}\right]_{\mathrm{i}}$ response in cerebellar neurons. Consistent with the notion that intracellular $\mathrm{Ca}^{2+}$ from $\mathrm{IP}_{3}$-sensitive $\mathrm{Ca}^{2+}$ pools could play an important role in the mechanism of action of PACAP, incubation of the cells with $2 \mathrm{APB}$, a cell permeable D-myo-inositol 


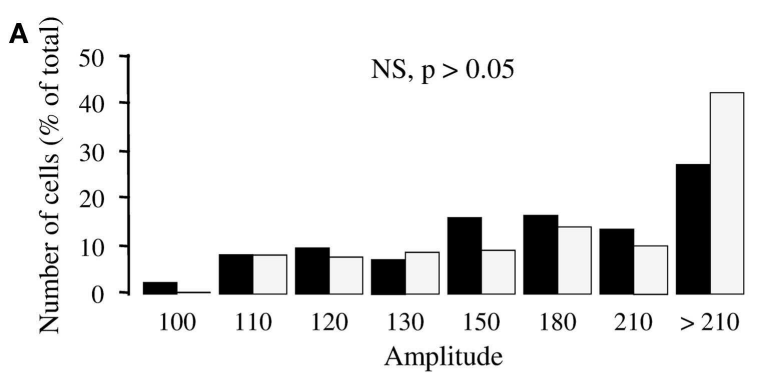

PACAP38 $\square$ nifedipine + PACAP38

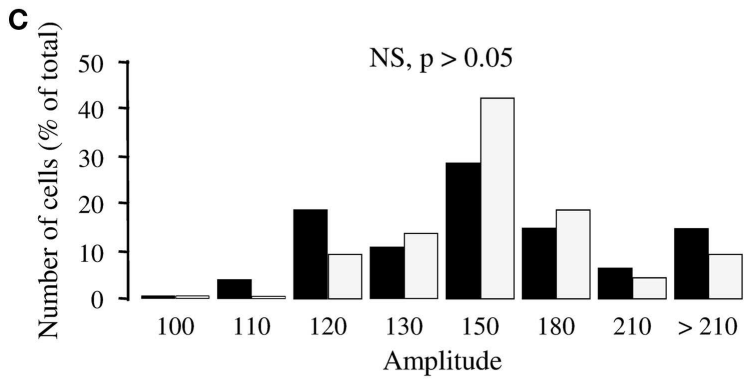

PACAP38 $\square$ w-conotoxin MVIIC + PACAP38

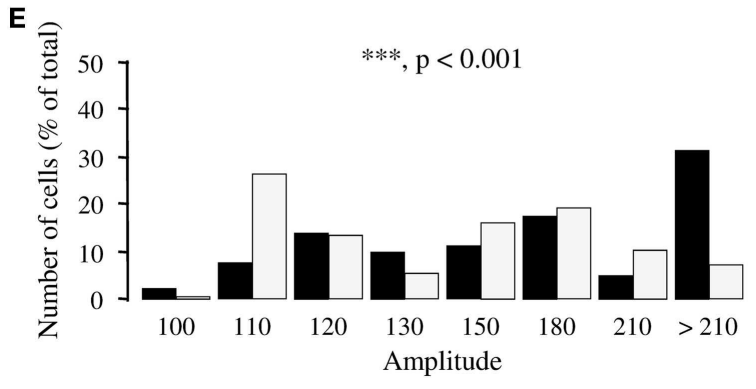

PACAP38

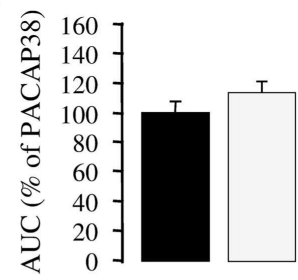

PACAP38 $\square$ nifedipine + PACAP38

D

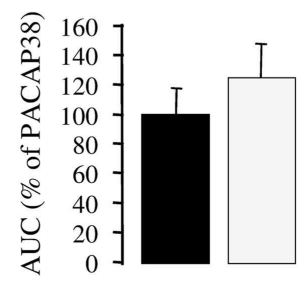

FIGURE 5 | Effect of selective blockers of voltage-operated calcium channels on calcium influx induced by PACAP38 in cerebellar granule cells. (A-F) Histograms showing the effect of a single application of $10^{-6} \mathrm{M}$ PACAP38 on the amplitude $(\mathbf{A}, \mathbf{C}, \mathbf{E})$ and the area under the curve $\mathbf{( B , D , F )}$ of the $\left[\mathrm{Ca}^{2+}\right]_{\mathrm{i}}$ response in the absence (black bars) or presence (white bars) of $10^{-5} \mathrm{M}$ of the L-type $\mathrm{Ca}^{2+}$ channel blocker nifedipine $(\mathbf{A}, \mathbf{B}), 10^{-6} \mathrm{M}$ of the Pand Q-type $\mathrm{Ca}^{2+}$ channel blocker $\omega$-conotoxin MVIIC (C,D), or $10^{-6} \mathrm{M}$ of the
$\mathrm{N}$-type $\mathrm{Ca}^{2+}$ channel blocker $\omega$-conotoxin GVIA (E,F). Nifedipine, $\omega$-conotoxin MVIIC, and $\omega$-conotoxin GVIA were added to the incubation medium $30 \mathrm{~min}$ before application of the pulse of PACAP38. (A,C,E) Histograms showing the distribution of granule cells according to the amplitude of their response to PACAP. Each graph represents the analysis of a least 50 cells from 3 different cultures. AUC, area under the curve; NS, not significantly different from the PACAP38; ${ }^{* * *} p<0.001$. 1,4,5-trisphosphate receptor antagonist, decreased the $\left[\mathrm{Ca}^{2+}\right]_{\mathrm{i}}$ response to PACAP. Such a contribution of intracellular $\mathrm{Ca}^{2+}$ stores to the PACAP-evoked $\left[\mathrm{Ca}^{2+}\right]_{\mathrm{i}}$ response has already been reported in rat gonadotrophs (Rawlings et al., 1994), in rat acinar AR42J cells (Barnhart et al., 1997), and in human neutrophils (Harfi and Sariban, 2006).

Alongside, suppression of extracellular $\mathrm{Ca}^{2+}$ by EGTA or exposure of cells to the non-selective $\mathrm{Ca}^{2+}$ channel blocker $\mathrm{NiCl}_{2}$, also attenuated the stimulatory effect of PACAP38 on $\left[\mathrm{Ca}^{2+}\right]_{i}$, indicating that $\mathrm{Ca}^{2+}$ influx is also required for the transient phase of the $\left[\mathrm{Ca}^{2+}\right]_{\mathrm{i}}$ increase. Recruitment of both intracellular and extracellular sources of $\mathrm{Ca}^{2+}$ after activation of $\mathrm{PAC} 1$ receptors has already been reported in several models including the rat acinar cell line AR42J (Barnhart et al., 1997), the human neuroblastoma cell line NB-OK-1 (Delporte et al., 1993), and primary cultures of rat cortical neurons (Grimaldi and Cavallaro, 1999). To determine which type of $\mathrm{Ca}^{2+}$ channel was responsible for the stimulatory effect of PACAP on calcium influx, selective blockers 
of VOCCs were used. Preincubation of granule cells with the $\mathrm{N}$-type $\mathrm{Ca}^{2+}$ channel blocker $\omega$-conotoxin GVIA decreased the PACAP-evoked $\left[\mathrm{Ca}^{2+}\right]_{\mathrm{i}}$ response, whereas the L-type $\mathrm{Ca}^{2+}$ channel blocker nifedipine and the $\mathrm{P}$ - and Q-type $\mathrm{Ca}^{2+}$ channel blocker $\omega$-conotoxin MVIIC had no effect. These findings contrast with previous data showing the involvement of L-type $\mathrm{Ca}^{2+}$ channels in the stimulatory effect of PACAP on human neutrophils (Harfi et al., 2005), on porcine somatotrope cells (Martinez-Fuentes et al., 1998) or on bovine adrenal chromaffin cells (Tanaka et al., 1996) and the implication of T-type $\mathrm{Ca}^{2+}$ channels in mouse adrenal chromaffin cells (Hill et al., 2011). Nevertheless, other factors acting on cerebellar granule neurons, such as IGF-1, have already been shown to regulate $\mathrm{N}$-type $\mathrm{Ca}^{2+}$-channels (Blair and Marshall, 1997).

$\mathrm{Ca}^{2+}$ is an essential intracellular messenger required for numerous cellular functions (Carafoli et al., 2001). For instance, during development, modifications of intracellular $\mathrm{Ca}^{2+}$ concentrations have been shown to regulate proliferation (Owens et al., 2000), migration (Komuro and Rakic, 1992), differentiation (Benquet et al., 2002; Ronn et al., 2002), and apoptosis (Turner et al., 2002) of immature neurons. Various studies suggest that, depending on the pool involved, $\mathrm{Ca}^{2+}$ can exert different effects on immature neurons. For instance, in rat cortical neurons, $\mathrm{Ca}^{2+}$ release from intracellular stores is implicated in neurite elongation, while $\mathrm{Ca}^{2+}$ influx regulates dendritic branching (Ramakers et al., 2000). In the immature cerebellum, a transient elevation of intracellular $\mathrm{Ca}^{2+}$ levels increases the migration rate of granule neuroblasts (Komuro and Rakic, 1996) and the thapsigargin-sensitive $\mathrm{Ca}^{2+}$ store plays an essential role in growth and maturation of cerebellar granule cells (Yao et al., 1999). Even though the implication of $\mathrm{Ca}^{2+}$ on granule cell development is now well established, the neurotrophic factors able to control $\mathrm{Ca}^{2+}$ levels in cerebellar neuroblasts are not yet clearly identified. Nevertheless, peptides acting on $\mathrm{G}$ protein-coupled receptors are thought to be important mediators to control neurite outgrowth and growth cone guidance in cerebellar granule cells through a $\mathrm{Ca}^{2+}$-dependent pathway (Xiang et al., 2002).

Granule cells are, by far, the major population of interneurons in the cerebellum and they represent the main source of glutamate, the second most abundant population being GABAergic neurons (Voogd and Glickstein, 1998). Previous studies have demonstrated that plasticity of granule cells can be modulated by neuropeptides (Cote et al., 1999; Yacubova and Komuro, 2002). In particular, in cerebellar granule cells, PACAP has been shown to inhibit proliferation (Nicot et al., 2002), stop migration (Cameron et al., 2007), protect from apoptosis (Vaudry et al., 2000), and

\section{REFERENCES}

Aoyagi, K., and Takahashi, M. (2001). Pituitary adenylate cyclaseactivating polypeptide enhances $\mathrm{Ca}(2+)$-dependent neurotransmitter release from $\mathrm{PC} 12$ cells and cultured cerebellar granule cells without affecting intracellular $\mathrm{Ca}(2+)$ mobilization. Biochem. Biophys. Res. Commun. 286, 646-651.

Barnhart, D. C., Sarosi, G. A. Jr., and Mulholland, M. W. (1997).

promote differentiation (Gonzalez et al., 1997). In vivo, PACAP receptors are expressed by precursors of cerebellar granule cells in the external granule cell layer (Basille et al., 1993) and PACAP administration increases the number of mature neurons in the post-migratory internal granule cell layer (Vaudry et al., 1999). The implication of adenylyl cyclase and MAP kinases in the effects of PACAP have been extensively investigated (Villalba et al., 1997; Vaudry et al., 1998; Nicot et al., 2002) but the contribution of PACAP-induced $\mathrm{Ca}^{2+}$ increase in maturation of cerebellar neuroblasts is still poorly understood. So far, it has only been shown that calcium is involved in the inhibitory effect of PACAP on granule cell migration (Cameron et al., 2007). However, it is well established that potassium depolarization-induced $\mathrm{Ca}^{2+}$ entry is essential for granule cell survival (Gallo et al., 1987), suggesting that the antiapoptotic effect of PACAP may involve calcium mobilization. As reported with cortical neurons, PACAP may induce BDNF expression in a $\mathrm{Ca}^{2+}$-dependent manner to indirectly promote granule cell survival (Shintani et al., 2005; Kokubo et al., 2009). The stimulation of granule cell proliferation by calcium influx is suppressed by nifedipine but not by $\omega$-conotoxin GVIA (Borodinsky and Fiszman, 1998), suggesting that the ability of PACAP to block granule cell division does not depend on calcium regulation. Consistent with this latter hypothesis, it has been shown that, in cortical neurons, PACAP inhibits cell proliferation through activation of the CAMP signaling pathway (Nicot and DiCicco-Bloom, 2001). Finally, potassium depolarization and NMDA treatment require calcium influx to induce neurofilament assembly in cerebellar granule cells (Bui et al., 2003), supporting the idea that PACAP-induced neurite outgrowth also requires calcium mobilization.

Altogether, these data indicate that some of the activities of PACAP on cerebellar granule cell proliferation, survival, migration, and differentiation involve, at least in part, intracellular and/or extracellular calcium mobilization, but further investigations are needed to decipher the precise role of calcium in each process.

\section{ACKNOWLEDGMENTS}

The authors want to thank Dr. Arnaud Arabo, Mrs. Huguette Lemonnier, and Mr. Donovan Liot for skillful technical assistance. David Vaudry and Hubert Vaudry are Affiliated Professors at the Institut National de la Recherche Scientifique - Institut Armand Frappier. This study was supported by grants from INSERM (U982), the Interreg TC2N project, the LARC-Neuroscience network, and the Région HauteNormandie.

Basille, M., Gonzalez, B. J., Fournier, A. and Vaudry, H. (1994). Ontogeny of pituitary adenylate cyclaseactivating polypeptide (PACAP) receptors in the rat cerebellum: a quantitative autoradiographic study. Brain Res. Dev. Brain Res. 82 81-89.

Basille, M., Gonzalez, B. J., Leroux, P., Jeandel, L., Fournier, A., and Vaudry, H. (1993). Localization and characterization of PACAP receptors in the rat cerebellum during development: evidence for a stimulatory effect of PACAP on immature cerebellar granule cells. Neuroscience 57, 329-338.

Benquet, P., Le Guen, J., Pichon, Y., and Tiaho, F. (2002). Differential involvement of $\mathrm{Ca}(2+)$ channels in survival and neurite outgrowth of cultured embryonic cockroach brain neurons. J. Neurophysiol. 88, 1475-1490.

Blair, L. A., and Marshall, J. (1997). IGF-1 modulates $\mathrm{N}$ and $\mathrm{L}$ calcium 
channels in a PI 3-kinase-dependent manner. Neuron 19, 421-429.

Borodinsky, L. N., and Fiszman, M. L. (1998). Extracellular potassium concentration regulates proliferation of immature cerebellar granule cells. Brain Res. Dev. Brain Res. 107, 43-48.

Botia, B., Basille, M., Allais, A., Raoult, E., Falluel-Morel, A., Galas, L., et al. (2007). Neurotrophic effects of PACAP in the cerebellar cortex. Peptides 28, 1746-1752.

Bui, C. J., Beaman-Hall, C. M., and Vallano, M. L. (2003). Ca2+ and $\mathrm{CaM}$ kinase regulate neurofilament expression. Neuroreport 14, 2073-2077.

Cameron, D. B., Galas, L., Jiang, Y., Raoult, E., Vaudry, D., and Komuro, H. (2007). Cerebellar cortical-layerspecific control of neuronal migration by pituitary adenylate cyclaseactivating polypeptide. Neuroscience 146, 697-712.

Canny, B. J., Rawlings, S. R., and Leong, D. A. (1992). Pituitary adenylate cyclase-activating polypeptide specifically increases cytosolic calcium ion concentration in rat gonadotropes and somatotropes. Endocrinology 130, 211-215.

Carafoli, E., Santella, L., Branca, D., and Brini, M. (2001). Generation, control, and processing of cellular calcium signals. Crit. Rev. Biochem. Mol. Biol. 36, 107-260.

Cauvin, A., Buscail, L., Gourlet, P., De Neef, P., Gossen, D., Arimura, A., et al. (1990). The novel VIP-like hypothalamic polypeptide PACAP interacts with high affinity receptors in the human neuroblastoma cell line NB-OK. Peptides 11, 773-777.

Cebolla, B., Fernandez-Perez, A., Perea, G., Araque, A., and Vallejo, M. (2008). DREAM mediates cAMPdependent, $\mathrm{Ca} 2+$-induced stimulation of GFAP gene expression and regulates cortical astrogliogenesis. $J$. Neurosci. 28, 6703-6713.

Chatterjee, T. K., Sharma, R. V., and Fisher, R. A. (1996). Molecular cloning of a novel variant of the pituitary adenylate cyclase-activating polypeptide (PACAP) receptor that stimulates calcium influx by activation of L-type calcium channels. J. Biol. Chem. 271, 32226-32232.

Cote, F., Do, T. H., Laflamme, L., Gallo, J. M., and Gallo-Payet, N. (1999). Activation of the AT(2) receptor of angiotensin II induces neurite outgrowth and cell migration in microexplant cultures of the cerebellum. J. Biol. Chem. 274, 31686-31692.

Delporte, C., Van Praet, A., Herchuelz, A., Winand, J., and Christophe,
J. (1993). Contrasting effects of PACAP and carbachol on $[\mathrm{Ca} 2+] \mathrm{i}$ and inositol phosphates in human neuroblastoma NB-OK-1 cells. Peptides 14, 1111-1118.

Dziema, H., and Obrietan, K. (2002). PACAP potentiates L-type calcium channel conductance in suprachiasmatic nucleus neurons by activating the MAPK pathway. J. Neurophysiol. 88, 1374-1386.

Gallo, V., Kingsbury, A., Balazs, R., and Jorgensen, O. S. (1987). The role of depolarization in the survival and differentiation of cerebellar granule cells in culture. J. Neurosci. 7, 2203-2213.

Gonzalez, B. J., Basille, M., Vaudry, D., Fournier, A., and Vaudry, H. (1997). Pituitary adenylate cyclaseactivating polypeptide promotes cell survival and neurite outgrowth in rat cerebellar neuroblasts. Neuroscience 78, 419-430.

Gracia-Navarro, F., Lamacz, M., Tonon, M. C., and Vaudry, H. (1992). Pituitary adenylate cyclase-activating polypeptide stimulates calcium mobilization in amphibian pituitary cells. Endocrinology 131, 1069-1074.

Grimaldi, M., and Cavallaro, S. (1999). Functional and molecular diversity of PACAP/VIP receptors in cortical neurons and type I astrocytes. Eur. J. Neurosci. 11, 2767-2772.

Harfi, I., Corazza, F., D'Hondt, S., and Sariban, E. (2005). Differential calcium regulation of proinflammatory activities in human neutrophils exposed to the neuropeptide pituitary adenylate cyclaseactivating protein. J. Immunol. 175, 4091-4102.

Harfi, I., and Sariban, E. (2006). Mechanisms and modulation of pituitary adenylate cyclase-activating proteininduced calcium mobilization in human neutrophils. Ann. N. Y. Acad. Sci. 1070, 322-329.

Harmar, A. J., Fahrenkrug, J., Gozes, I., Laburthe, M., May, V., Pisegna, J. R., et al. (2012). Pharmacology and functions of receptors for vasoactive intestinal peptide and pituitary adenylate cyclase-activating polypeptide. Br. J. Pharmacol. 166, 4-17.

Hezareh, M., Schlegel, W., and Rawlings, S. R. (1996). PACAP and VIP stimulate $\mathrm{Ca} 2+$ oscillations in rat gonadotrophs through the PACAP/VIP type 1 receptor (PVR1) linked to a pertussis toxin-insensitive G-protein and the activation of phospholipase C-beta. J. Neuroendocrinol. 8, 367-374.

Hill, J., Chan, S. A., Kuri, B., and Smith, C. (2011). Pituitary adenylate cyclase-activating peptide (PACAP) recruits low voltage-activated T-type calcium influx under acute sympathetic stimulation in mouse adrenal chromaffin cells. J. Biol. Chem. 286, 42459-42469.

Holighaus, Y., Mustafa, T., and Eiden, L. E. (2011). PAC1hop, null and hip receptors mediate differential signaling through cyclic AMP and calcium leading to splice variantspecific gene induction in neural cells. Peptides 32, 1647-1655.

Isobe, K., Nakai, T., and Takuwa, Y. (1993). Ca(2+)-dependent stimulatory effect of pituitary adenylate cyclase-activating polypeptide on catecholamine secretion from cultured porcine adrenal medullary chromaffin cells. Endocrinology 132, 1757-1765.

Jolivel, V., Basille, M., Aubert, N., de Jouffrey, S., Ancian, P., Le Bigot, J. F., et al. (2009). Distribution and functional characterization of pituitary adenylate cyclase-activating polypeptide receptors in the brain of non-human primates. Neuroscience 160, 434-451.

Kaddour, H., Hamdi, Y., Vaudry, D. Basille, M., Desrues, L., Leprince, J., et al. (2013). The octadecaneuropeptide ODN prevents 6-hydroxydopamine-induced apoptosis of cerebellar granule neurons through a PKC-MAPKdependent pathway. J. Neurochem. 125, 620-633.

Kienlen-Campard, P., Crochemore, C. Rene, F., Monnier, D., Koch, B., and Loeffler, J. P. (1997). PACAP type I receptor activation promotes cerebellar neuron survival through the cAMP/PKA signaling pathway. DNA Cell Biol. 16, 323-333.

Kokubo, M., Nishio, M., Ribar, T. J., Anderson, K. A., West, A. E., and Means, A. R. (2009). BDNFmediated cerebellar granule cell development is impaired in mice null for CaMKK2 or CaMKIV. $J$. Neurosci. 29, 8901-8913.

Komuro, H., and Rakic, P. (1992). Selective role of N-type calcium channels in neuronal migration. Science 257 , 806-809.

Komuro, H., and Rakic, P. (1996). Intracellular $\mathrm{Ca} 2+$ fluctuations modulate the rate of neuronal migration. Neuron 17, 275-285.

Levi, A. C., DeMattei, M., Ravazzani, R., Corvetti, G., Golden, G. T., and Fariello, R. G. (1989). Effects of 1-methyl-4-phenyl1,2,3,6-tetrahydropyridine (MPTP) on ultrastructure of nigral neuromelanin in Macaca fascicularis. Neurosci. Lett. 96, 271-276.
Martinez-Fuentes, A. J., Castano, J. P., Malagon, M. M., VazquezMartinez, R., and Gracia-Navarro, F. (1998). Pituitary adenylate cyclaseactivating polypeptides 38 and 27 increase cytosolic free $\mathrm{Ca} 2+$ concentration in porcine somatotropes through common and distinct mechanisms. Cell Calcium 23, 369-378.

Masuo, Y., Matsumoto, Y., Tokito, F., Tsuda, M., and Fujino, M. (1993). Effects of vasoactive intestinal polypeptide (VIP) and pituitary adenylate cyclase activating polypeptide (PACAP) on the spontaneous release of acetylcholine from the rat hippocampus by brain microdialysis. Brain Res. 611, 207-215.

Matsuda, K., Nejigaki, Y., Satoh, M., Shimaura, C., Tanaka, M., Kawamoto, K., et al. (2008). Effect of pituitary adenylate cyclase-activating polypeptide (PACAP) on prolactin and somatolactin release from the goldfish pituitary in vitro. Regul. Pept. 145, 72-79.

Mei, Y. A. (1999). High-voltageactivated calcium current and its modulation by dopamine D4 and pituitary adenylate cyclase activating polypeptide receptors in cerebellar granule cells. Zhongguo Yao Li Xue Bao 20, 3-9.

Michel, S., Itri, J., Han, J. H., Gniotczynski, K., and Colwell, C. S. (2006). Regulation of glutamatergic signalling by PACAP in the mammalian suprachiasmatic nucleus. $\mathrm{BMCNeu}$ rosci. 7:15. doi:10.1186/1471-22027-15

Miyata, A., Arimura, A., Dahl, R. R., Minamino, N., Uehara, A., Jiang, L., et al. (1989). Isolation of a novel 38 residue-hypothalamic polypeptide which stimulates adenylate cyclase in pituitary cells. Biochem. Biophys. Res. Commun. 164, 567-574.

Mustafa, T., Grimaldi, M., and Eiden, L. E. (2007). The hop cassette of the PAC1 receptor confers coupling to $\mathrm{Ca} 2+$ elevation required for pituitary adenylate cyclaseactivating polypeptide-evoked neurosecretion. J. Biol. Chem. 282, 8079-8091.

Nicot, A., and DiCicco-Bloom, E. (2001). Regulation of neuroblast mitosis is determined by PACAP receptor isoform expression. Proc. Natl. Acad. Sci. U.S.A. 98, 4758-4763.

Nicot, A., Lelievre, V., Tam, J., Waschek, J. A., and DiCicco-Bloom, E. (2002). Pituitary adenylate cyclaseactivating polypeptide and sonic 
hedgehog interact to control cerebellar granule precursor cell proliferation. J. Neurosci. 22, 9244-9254.

Owens, D. F., Flint, A. C., Dammerman, R. S., and Kriegstein, A. R. (2000). Calcium dynamics of neocortical ventricular zone cells. Dev. Neurosci. 22, 25-33.

Ramakers, G. M., Pasinelli, P., van Beest, M., van der Slot, A., Gispen, W. H., and De Graan, P. N. (2000). Activation of pre- and postsynaptic protein kinase $\mathrm{C}$ during tetraethylammonium-induced long-term potentiation in the CA1 field of the hippocampus. Neurosci. Lett. 286, 53-56.

Rawlings, S. R., Canny, B. J., and Leong, D. A. (1993). Pituitary adenylate cyclase-activating polypeptide regulates cytosolic $\mathrm{Ca} 2+$ in rat gonadotropes and somatotropes through different intracellular mechanisms. Endocrinology 132, 1447-1452.

Rawlings, S. R., Demaurex, N., and Schlegel, W. (1994). Pituitary adenylate cyclase-activating polypeptide increases [Ca2] i in rat gonadotrophs through an inositol trisphosphatedependent mechanism. J. Biol. Chem. 269, 5680-5686.

Reglodi, D., Kiss, P., Szabadfi, K., Atlasz, T., Gabriel, R., Horvath, G., et al. (2012). PACAP is an endogenous protective factor-insights from PACAP-deficient mice. J. Mol. Neurosci. 48, 482-492.

Ronn, L. C., Dissing, S., Holm, A., Berezin, V., and Bock, E. (2002). Increased intracellular calcium is required for neurite outgrowth induced by a synthetic peptide ligand of NCAM. FEBS Lett. 518, 60-66.

Sato, M., Suzuki, K., Yamazaki, H., and Nakanishi, S. (2005). A pivotal role of calcineurin signaling in development and maturation of postnatal cerebellar granule cells. Proc. Natl. Acad. Sci. U.S.A. 102, 5874-5879.

Shintani, N., Suetake, S., Hashimoto, H., Koga, K., Kasai, A., Kawaguchi, C., et al. (2005). Neuroprotective action of endogenous PACAP in cultured rat cortical neurons. Regul. Pept. 126, 123-128.

Tanaka, K., Shibuya, I., Nagamoto, T., Yamashita, H., and Kanno, T. (1996). Pituitary adenylate cyclaseactivating polypeptide causes rapid $\mathrm{Ca} 2+$ release from intracellular stores and long lasting Ca2+ influx mediated by $\mathrm{Na}$ (influx-dependent membrane depolarization in bovine adrenal chromaffin cells. Endocrinology 137, 956-966.

Tatsuno, I., and Arimura, A. (1994). Pituitary adenylate cyclaseactivating polypeptide (PACAP) mobilizes intracellular free calcium in cultured rat type-2, but not type-1, astrocytes. Brain Res. 662, $1-10$.

Tatsuno, I., Yada, T., Vigh, S., Hidaka, H., and Arimura, A. (1992). Pituitary adenylate cyclase activating polypeptide and vasoactive intestinal peptide increase cytosolic free calcium concentration in cultured rat hippocampal neurons. Endocrinology 131, 73-81.

Turner, C. P., Pulciani, D., and Rivkees, S. A. (2002). Reduction in intracellular calcium levels induces injury in developing neurons. Exp. Neurol. 178, 21-32.

Vaudry, D., Falluel-Morel, A., Bourgault, S., Basille, M., Burel, D., Wurtz, O., et al. (2009). Pituitary adenylate cyclase-activating polypeptide and its receptors: 20 years after the discovery. Pharmacol. Rev. 61, 283-357.

Vaudry, D., Gonzalez, B. J., Basille, M., Anouar, Y., Fournier, A., and Vaudry, H. (1998). Pituitary adenylate cyclase-activating polypeptide stimulates both c-fos gene expression and cell survival in rat cerebellar granule neurons through activation of the protein kinase A pathway. Neuroscience 84, 801-812.

Vaudry, D., Gonzalez, B. J., Basille, M., Fournier, A., and Vaudry,
H. (1999). Neurotrophic activity of pituitary adenylate cyclaseactivating polypeptide on rat cerebellar cortex during development. Proc. Natl. Acad. Sci. U.S.A. 96, 9415-9420.

Vaudry, D., Gonzalez, B. J., Basille, M., Pamantung, T. F., Fontaine, M., Fournier, A., et al. (2000). The neuroprotective effect of pituitary adenylate cyclase-activating polypeptide on cerebellar granule cells is mediated through inhibition of the CED3-related cysteine protease caspase-3/CPP32. Proc. Natl. Acad. Sci. U.S.A. 97, 13390-13395.

Villalba, M., Bockaert, J., and Journot, L. (1997). Pituitary adenylate cyclaseactivating polypeptide (PACAP-38) protects cerebellar granule neurons from apoptosis by activating the mitogen-activated protein kinase (MAP kinase) pathway. J. Neurosci. 17, 83-90.

Voogd, J., and Glickstein, M. (1998). The anatomy of the cerebellum. Trend Cogn. Sci. (Regul. Ed.) 2, 307-313.

Watanabe, T., Masuo, Y., Matsumoto, H., Suzuki, N., Ohtaki, T., Masuda, Y., et al. (1992). Pituitary adenylate cyclase activating polypeptide provokes cultured rat chromaffin cells to secrete adrenaline. Biochem. Biophys. Res. Commun. 182, 403-411.

Xiang, Y., Li, Y., Zhang, Z., Cui, K., Wang, S., Yuan, X. B., et al. (2002). Nerve growth cone guidance mediated by G protein-coupled receptors. Nat. Neurosci. 5, 843-848.

Yacubova, E., and Komuro, H. (2002). Stage-specific control of neuronal migration by somatostatin. Nature 415, 77-81.

Yada, T., Sakurada, M., Ihida, K., Nakata M., Murata, F., Arimura, A., et al. (1994). Pituitary adenylate cyclase activating polypeptide is an extraordinarily potent intra-pancreatic regulator of insulin secretion from islet beta-cells. J. Biol. Chem. 269, 1290-1293.

Yada, T., Vigh, S., and Arimura, A. (1993). Pituitary adenylate cyclase activating polypeptide (PACAP) increases cytosolic-free calcium concentration in folliculo-stellate cells and somatotropes of rat pituitary. Peptides 14, 235-239.

Yan, Y., Zhou, X., Pan, Z., Ma, J., Waschek, J. A., and Dicicco-Bloom, E. (2013). Pro- and anti-mitogenic actions of pituitary adenylate cyclase-activating polypeptide in developing cerebral cortex: potential mediation by developmental switch of PAC1 receptor mRNA isoforms. J. Neurosci. 33, 3865-3878.

Yao, C. J., Lin, C. W., and LinShiau, S. Y. (1999). Roles of thapsigargin-sensitive $\mathrm{Ca} 2+$ stores in the survival of developing cultured neurons. J. Neurochem. 73, 457-465.

Conflict of Interest Statement: The authors declare that the research was conducted in the absence of any commercial or financial relationships that could be construed as a potential conflict of interest.

Received: 03 April 2013; accepted: 25 April 2013; published online: 10 May 2013.

Citation: Basille-Dugay M, Vaudry $H$, Fournier A, Gonzalez B and Vaudry D (2013) Activation of PAC1 receptors in rat cerebellar granule cells stimulates both calcium mobilization from intracellular stores and calcium influx through $\mathrm{N}$ type calcium channels. Front. Endocrinol. 4:56. doi: 10.3389/fendo.2013.00056

This article was submitted to Frontiers in Neuroendocrine Science, a specialty of Frontiers in Endocrinology.

Copyright (C) 2013 Basille-Dugay, Vaudry, Fournier, Gonzalez and Vaudry. This is an open-access article distributed under the terms of the Creative Commons Attribution License, which permits use, distribution and reproduction in other forums, provided the original authors and source are credited and subject to any copyright notices concerning any third-party graphics etc. 